into the Black Sea ${ }^{6}$, we might expect to find $S$. gaederopus also. However, according to Shackleton and Renfrew ${ }^{1}$, the radiometric age of the examined Spondylus shells is only 2,500 BC and $4,000 \mathrm{BC}$.

It is therefore concluded that, at least for this special case, the ${ }^{18 / 16} \mathrm{O}$ method is irrelevant. Finally, $S$. gaederopus lives today along various Mediterranean coasts (Algeria, France, Italy, Israel, and so on) cemented to some rocky substrate, and it would probably be very difficult to tell from the isotopic composition the exact geographical location (that is Aegean or Adriatic) where the samples were collected.

\section{Yours faithfully,}

\section{S. Moshkovitz}

Department of Geology, Hebrew Univeriity of Jerusalem
${ }^{1}$ Shackleton, N., and Renfrew, C., Nature, 228, 1062 (1970).

${ }^{2}$ Bucquoy, E., Dautzenberg, Ph., and Dollfus, G. (B.D.D.), Les Mollusques marine de Roussillon (1882-1898).

${ }^{3}$ Moshkovitz, S., in Bear, L. M., Palaeontological Notes, Ann. Rep. for the Year 1962 (Geol. Surv. Dept., Cyprus).

${ }^{4}$ Bukry, D., King, S., Horn, M. K., and Manheim, F. T., Nature, 226, 156 (1970).

5 Butzer, K. W., Encyclopedia of Oceanography (edit. by Fairbridge) (Reinhold Publ. Corp., 1966).

${ }^{6}$ Caspers, H., Geol. Soc. Amer. Mem. 67, 1, 801 (1957).

\section{Announcements}

\section{University News}

Professor P. M. Maitlis, McMaster University, has been appointed to the chair of inorganic chemistry, University of Sheffield.

\section{Appointments}

Mr W. A. Cumming and Dr J. D. Keys have each been appointed assistant vicepresident (laboratories) of the National Research Council of Canada.

Graham Morris, manager of the Education and Training Division of $\mathrm{ICL}$, has been appointed deputy president of the British Computer Society for 1971-72.

Sir Ronald Baskett has been appointed secretary of the Agricultural Research Council, in succession to Sir Gordon Cox. Mr D. J. Parkinson has been appointed under secretary, and Dr C. C. Webster has been appointed chief scientific officer.

\section{Miscellaneous}

The Academy of Sciences of the USSR has been awarded the International Galaber Prize for the research projects carried out by the automatic spacecraft Luna-16.

Dr F. B. A. Giwa, University of Ibadan, has been awarded the first World Meteoro- logical Organization Research Award for Regional Association I (Africa), in recognition of his work on the effect of wind on the resonant period of the atmosphere.

\section{Erratum}

IN the article "Australia's Caenozoic Drift" by J. G. Jones (Nature, 230, 237; 1971), the first sentence of the penultimate paragraph should read "A final problem which Australia's Caenozoic drift may elucidate is the origin of the Coral Sea".

\section{British Diary}

517th Meeting (two days) Biochemical Society, in the Appleton Tower, University of Edinburgh, George Square, Edinburgh. Biological Hydroxylation Mechanisms (symposium); and meeting for the presentation of free communications.

\section{Reports and Publications}

not included in the monthly Books Supplement

\section{Other Countries}

Carte Pédologique de la France au 1/100.000. Argeles-sur-Mer-Perpignan, L. 24 et L. 25. Notice explicative par J. Servant. Pp. 114. (Versailles: Institut National de la Recherche Agronomique, 1970. ) 53.75 francs

Nederlandse Vereniging voor Weer- en Sterrenkunde. Observations of Variable Stars, July-December 1970 Report No, 19.) Pp. 7. (Groningen, Netherlands: Kapteyn Astronomical Laboratory, 1971.) [274
CERN-European Organization for Nuclear Research. CERN 71-8: Spin Formalisms. By S. U. Chung. (Lectures given in the Academic Training Programme of CERN 1969-1970. Pp. v+81. (Geneva: CERN, National Academy of Sciences; National Academy of Engineering; National Research Council. Organization and Members 1970/1971. Pp. 243. (Washington, DC: National Academy of Sciences; National Academy

NINDS Research Profiles: 1970-Summary of Research at the National Institute of Neurological Delion. Institutes of Health) Pp vii +57. (Washing Government Printing $\mathrm{Pp}$. vil 1 (1970) (Washington, DC Health Sciences in Israel Institutions and Scientists. dited by Betty Davies. Pp. x +285 . (Jerusalem: Isroe Journal of Medical Sciences, 1971) 87 . US Department of the Interior: Geological Survey. Professional Paper 537-E: Chronological Narrative of of the 1959/1960 Eruption of Kilauea Volcano, Hawaii. By D. H. Richter, J. P. Eaton, K. J. Murata, W. U. Paper 1878: Water Resources of Racine and Kenoshy Counties, South-eastern Wisconsin. By Rickard D. Hutchinson. Pp. v+63+4 plates. (Washington, DC:
Government Printing Office, 1970.)

US Department of the Interior: Geological Survey. Water-Supply Paper 1879-C: Ground-Water Aspects of the Lower Henrys Fork Region, Eastern Idaho. By E. G Crosthwaite, Pp. iii + 22+1 plate. \$0.70. Water-Supply Paper 1895-B: Summary of Data on Chemical Ouality of Streams Notth Carolina, 1943-67. By Hugh B. Wilder and Larry J. Slack. Pp. iv $+236+2$ plates. (Washington, US Department of the Interior: Fish and Wildlife Service. Bureau of National Wildlife Refuges. Pp. 28. \$0.35, Wildlife Research: Problems, Programs, Progress, 1968. Pp. viii + 112. \$1.25. (Washington, DC: Government Printing Office, 1970.)

Research Council of Alberta. Annual Report 1970. Pp. 75. (Edmonton: Research Council of Alberta,

Smithsonian Contributions to Paleobiology. No 3 : Paleozoic Perspectives - Paleontological Ty. No. 3 G. Arthur Cooper. Edited by Thomas Durro Jr. Pp. xiv +390 . \$4. Smithsonian Contributions to No. 69: Biostatistical Programs in BASIC Language for Time-Shared Computers. Coordinated with the book "Quantitative Zoology". By James A. Peters. Pp. 46. \$0.50. No. 77: Bredin-Archbold-Smithsonian Biological Survey of Dominica-Burrowing Sponges, Genus Siphonodictyon Bergquist, from the Caribbean. By K. Rützler. Pp. 37. \$0.50. (Washington, DC Smithsonian Institution Press, 1971. For sale by US Government Printing Office.)

\section{HOW TO BUY NATURE}

Volumes start in January, March, May, July, September and November, but subscriptions may begin at any time.

The direct postal price per subscription is:

12 MONTHS * (52 issues per title)

\begin{tabular}{|c|c|c|c|}
\hline & \multirow{2}{*}{$\begin{array}{c}\text { Surface Mail } \\
\text { UK and } \\
\text { worldwide }\end{array}$} & \multicolumn{2}{|c|}{ Airfreight } \\
\hline & & U.S.A. & Canada \\
\hline Nature (Friday) & ⿷14 & $\$ 48$ & $\$ 52$ \\
\hline $\begin{array}{l}\text { Nature }+ \\
\text { Nature Physical Science }\end{array}$ & $£ 24$ & $\$ 83$ & $\$ 90$ \\
\hline $\begin{array}{l}\text { Nature }+ \\
\text { Nature New Biology }\end{array}$ & $\varepsilon 24$ & $\$ 83$ & $\$ 90$ \\
\hline All three editions & $£ 29.50$ & $\$ 108$ & $\$ 116$ \\
\hline Annual Index & £1 & $\$ 3$ & \$3 \\
\hline
\end{tabular}

- Rates for shorter periods pro rata (minimum three months) (Charge for delivery by air mail on application)
Editorial and Publishing Offices of NATURE

MACMILLAN JOURNALS LIMITED

4 LITTLE ESSEX STREET, LONDON WC2R 3LF

Telephona Number : 01-836 6633. Telegrams : Phusis London WC2R 3LF 711 NATIONAL PRESS BUILDING WASHINGTON DC 20004

Telephone Number : 202-737 2355 Subscription Department MACMILLAN JOURNALS LIMITED BRUNEL ROAD, BASINGSTOKE, HANTS

Telephone Number : Basingstoke 5431

American display advertisements

NATURE SCIENTIFIC PUBLICATIONS INC

711 NATIONAL PRESS BUILDING WASHINGTON DC 20004

All other advertisements

T. G. SCOTT \& SON, LIMITED

1 CLEMENT'S INN, LONDON WC2A 2ED

Telephone : 01-242 6264/01-4054743

Telegrams: Textualist London WC2A 2ED

Registered as a newspaper at the Post Office

Copyright (C) Macmillan Journals Limited, July 23, 1971 